\title{
Based on Regional Trade Analysis of Mechanism to Enhance Product Competitiveness
}

\author{
Yingjuan Feng (Corresponding author) \\ School of Economics and Management, Changchun University of Science and Technology \\ 7989 Weixing Road, Changchun 130022, China \\ Tel: 86-431-8628-7978Ｅ-mail: blessyandm@163.com \\ Yan Wang (Corresponding author) \\ School of Economics and Management, Changchun University of Science and Technology \\ 7989 Weixing Road, Changchun 130022, China \\ Tel: 86-431-8521-7930 E-mail: wangyan@163.com
}

Lili Wu (Corresponding author)

Changchun University of Science and Technology College of Optical and electronical Information 1000 Bocai Road, Changchun 130000, China

\begin{abstract}
The development of regional trade can enhance the competitiveness of products. In this paper, from two aspects of international trade and domestic regional trade discusses inherent mechanism of regional trade to enhance the product competitiveness.
\end{abstract}

Keywords: Regional trade, Product competitiveness, Enhance, Mechanism

\section{Introduction}

Regional trade is regional and interregional exchange activities of goods or services. Refer to the definition of region, can be as large as countries or States, as small as a single country of the county, township or neighborhood. Therefore, regional trade both includes international trade (that is, exchange activities of goods and services between a region of a country and that of the other countries), and regional trade within the country. So this article will be from international trade and regional trade within a country to analyze the sources of competitiveness of product respectively.

\section{Revealed Indicators of Evaluation for Regional Trade to Enhance the Competitiveness of Products}

The size of regional trade to enhance the competitiveness of product, you can evaluate through the following economic indicators:

\subsection{Product Sales}

Elimination of regional trade barriers and the development of domestic regional trade can enable enterprises face the broader market, under the same conditions, can have access to opportunities for greater market share, to produce a "trade creation effect" to promote enterprise sales increase in a specific period, which is a welfare increase. If the terms of trade do not deteriorate, the more product sales increase, indicating the larger of regional trade can boost the product competitiveness, otherwise the smaller is to be; if the terms of trade worsen, expand the size of regional trade may lead to "tragic growth".

\subsection{Profitability of Unit Product}

The development of regional trade expand product market share and production scale, while the enterprise get the effect of economies of scale, and meanwhile the development of specialization will make specialization economy, raising labor productivity greatly and reducing production costs; and the elimination of regional trade barriers will further promote competition among regional companies, bring innovative power and pressure, thereby enhancing the technological content of products, increase the added value of product, all this will eventually improve the unit profit margins. Therefore, the higher the profit margin per unit product make, the greater regional trade shows to promote the product competitiveness, on the contrary, to be the smaller. 


\section{The Explanation of International Trade Theory to Regional Economic Competitiveness}

Recalling the development course of international trade, we found international trade theory system improve itself continuously, analysis for the competitiveness is also closer to the real status of international competition at the same time.

\subsection{Exports over Imports, to Maintain a Country's Trade Surplus is a Source of competitiveness}

During 15-18 century, the mercantilists who dominate in international trade and balance of payments theory view that exports have a crucial role in a country's wealth accumulation and economic status consolidating and improving.

The basic ideas of mercantilist are:

(1) Currency (precious metals) is the only form of wealth;

(2) Countries should achieve a "favorable balance of trade" which exports over imports to ensure the inflow of precious metals and the increase in wealth;

(3) to expand exports, the Government needs to take a series of protectionism policies, including increased population, a low wage policy, manufacturing subsidies, import restrictions, building a strong navy, maintaining merchandise exports security, and so on.

\subsection{Difference in Labor Productivity or Factor Endowments among Nations is the Main Source of Competitiveness}

Traditional trade theory produced in the 18th century, completed in the 20th century. It mainly includes absolute advantage, comparative advantage and factor-endowment theory. From differences in labor productivity and natural resources of each nation, it reveals the motivation of international trade, and these two differences is the direct source of international industrial competitiveness. Main points are as follows:

(1) The absolute difference in labor productivity between countries is the source of a nation's competitiveness

Based on the critical point of view of mercantilism, Adam Smith's absolute advantage theory used the thinking of division of labor in research of international trade field. The theory point that the root cause of trade between countries is the absolute differences in production costs, this absolute cost differences that may come from both the innate natural advantages, such as climate, geography and soil conditions, and may be the acquired advantages formed with capital accumulation and technological progress. The absolute difference in production costs resulted in absolute difference of price while the two countries produce the same product, so that the international industrial division of labor and specialization becomes necessary. Through free trade, countries can exert the absolute manufacturing advantages; achieve the division of labor and professional interests. This theory makes the sources of industrial competitiveness due to the absolute difference between countries in labor productivity.

(2) The relative difference between countries in labor productivity is a major source of national competitiveness

David Ricardo's comparative advantage theory inherit the division of labor and free trade ideology of Adam Smith, and further expand the scope of labor productivity differences as motivation of international trade and the source of competitiveness.

However, the core argument of comparative advantage as: "to take advantage of two heavy, two drawbacks to take light." From its basic principles, comparative advantage theory continues to think differences in labor productivity as trade motivation and source of competitiveness, and it has a broader applicability and greater explanatory power. Meanwhile, a large number of empirical tests of this theory basically came to positive conclusions. These empirical studies have shown that relative to other countries a country with higher labor productivity generally has a strong ability to export, accordingly support the Ricardian trade model (D.A. MacDougall, 1951;R.M. Stem,1962;B.Balassa,1963)

(3) National differences in factor endowments is the main source of country's competitiveness

Factor endowment theory views that products need to put more than one factor, and production elements required for different products in different proportion. As degree of national differences in abundance of production factors, so result in a price difference between the factors of production and production costs difference of similar products, and that the cost difference becomes motivation and basis for international exchange, that is a country will export products which production intensive use their abundant factors, and import products which production intensive use relatively scarce factors. It can be inferred from this conclusion: the industry which intensive use its relatively abundant factor is the industry which has comparative advantage 
and competitiveness.

\subsection{Economies of Scale, Product Differentiation and Competitive Strategy of Enterprises is a Major Source of National Competitiveness}

(1) Economies of scale. The existence of economies of scale means that production expand, the average production costs decrease, benefit increases. Economies of scale include internal economies of scale and external economies of scale; the former is a result of corporate production increase and average cost decrease, while the latter refers to an industry average cost of each enterprise as the expansion of the industry production decline. Economies of scale are common features of modern manufacturing, especially in the steel, automotive, electronics, electricity, chemical industry, and the economies of scale even more prominent.

In the industries which have internal economies of scale, large firms through the international competition obtain more favorable market position. This point is easy to understand: international trade expend the product's overall market capacity, and then expand the cost advantage of large firms and Campaign fields of economies of scale, effectively eased the contradictions including which between limited domestic market and minimum production capacity achieving economies of scale, and between economies of scale and market competitiveness. Can be seen in the open economy, economies of scale and competitive advantage are mutually reinforcing.

For the industries which exist external economies of scale, economies of scale to make a country's industry has a comparative cost advantage, and become the exporting country among the industry.

(2) Product differentiation. Product Differentiation refers to the difference between similar products, which include two forms: vertical and. Vertical difference refers that quality differences, and horizontal difference means that the differences in level and combination characteristics of product. Industrial organization theory maintained that as a result of innovation, product differentiation constitutes an important source of competitive advantage. New trade theory also approves the role of heterogeneity in international competition. As the level of consumption of different countries, international trade can help achieve economies of scale, heterogeneous products, and stimulate consumer demand for imported goods, set preferences for imported goods, thereby enabling domestic manufacturers and import enterprises to re-segment the market, providing heterogeneous products, manufacturers and thus enjoyed a greater market share.

(3) Competitive strategy of enterprises. According to industrial organization theory, in a imperfectly competitive market, firms competitive strategy will directly affect their market position, thereby causing its market structure changes in the industry which they position, including the number of competitors, entry conditions, innovation trends of industry, technology and product and Comparison of market forces. This principle also applies to an open economy. New trade theory suggests that firms use competitive strategy as an important means of consolidate and improve market position, establish competitive advantage in the international market.

\section{4. the Internal Mechanism of Regional Trade to Enhance Product Competitiveness}

Effected by mainstream economics factors, analysis emphasize on time factor and ignore spatial factors, whether the traditional international trade theory which analyze country-units, or the new trade theory which consider companies and enterprises as the main analysis unit, are to the premise that domestic different interregional elements flow fully and trade opportunities are taken full advantage, inspect economic impact on international trade of a country (whether large or small), they all ignored the important fact which domestic regional trade influence international trade. In fact, as for the large nation which domestic trade opportunities have not been fully utilized, the domestic regional trade optimize the allocation of resources, realize the division, specialization and economies of scale, create the competitive environment that enterprise development need, and ultimately to enhance a country's products international competitiveness.

\subsection{Internal Economies of Scale Can Change International Competitive Advantage of the Products}

For large nation, if no domestic trade barriers, and domestic demand is large enough, then with the increase of the volume of domestic regional trade, and scale-up of domestic enterprises production scale, realization of economy of scale can reduce the average cost of product, to build the foundation for improving the price competitiveness. After the prices competitiveness increased, under other conditions, especially non-price competitiveness remain constant, not only strengthen the difficulties which foreign products enter into the domestic market, but also their previous products that do not compete with other country's products have may become competitive export products, thus changing the competitive advantage of the international situation.

\subsection{External Economies of Scale Save Production Cost}

Regional trade development of large nation will lead to gather many industries to a region to form economies of scale, economies of scale means that many industries to a region through focused cost savings. Economy of scale 
exists, because there is external economy among industries, that industrial agglomeration effect. On this point, most classic is Marshall's point of view. Marshall thought external economic effects that enterprises gather in particular region would mainly in the following areas: firstly, be able to use natural resources and human resources which have comparative advantage; secondly, can be shared social production condition, namely infrastructure, reduced complexity on infrastructure requirements, thus saving the cost of building infrastructure; thirdly, can form relatively high efficiency local labor market; fourthly, is to share specialized services to assist industry; fifthly, is conducive to the spread and proliferation of expertise.

All of above save the production cost and improve the competitiveness of products, mainly its price competitiveness.

\subsection{The Division of Labor and Specialization of Production Enhances the Regional Competitiveness of Products}

Adam Smith on the division theorem tells us that the division of labor restricted by the scope of market, while the division of labor can greatly improve labor productivity. Regional trade occurred, so companies face a nationwide market, which has necessary prerequisite for the division of labor development, to achieve the division of labor and specialization. When a company specializes in one product, with the increase of professional level of production activities, therefore the marginal or average labor productivity will be rising. From a cost point of view, is reflected in a certain range, the average cost decreasing with the increases of levels of specialization. We can also call the economic phenomena as specialization economy.

\subsection{The Development of Regional Trade Will Contribute to Foster the Competitive Environment}

First, the nationwide demand to generate business development and competitive environment, increase business opportunities for training in the domestic market, companies can face real competition from imports and be able to get the necessary training before entering the international market. Such as the Japanese consumer is electronics enthusiastic buyers who like to the latest styles, as a result the market of electronic products in Japan becomes the world's most competitive country. Similarly, the French are especially critical to perfume, in such an environment, companies have been adapt exercise capacity to so critical market. France thus became the most competitive products in the international perfume market. These examples illustrate the relationship between competitiveness in international trade and domestic market demand; at least it was reinforced by the characteristics of demand.

Second, regional trade can increase competition in the domestic market and corporate operating efficiency. If the major regions within the country can freely develop inter-regional trade, it can be connected the regional market of various regions into a unified domestic market. In this way, the business of all regions can face a large unified domestic market, is not their respective small regional markets for production and management, so enterprises can eliminate monopoly of the local markets, which can form an effective competitive market structure. According to the basic theory that market structure determines market performance, in the effective competition market structure, we can effectively enhance competition in the market, improve business efficiency.

We can be seen from the above analysis, the development of regional trade can enhance the competitiveness of their products, and thereby enhancing the competitiveness of regional economy, as the competitiveness of products is the display of components of regional economic competitiveness. Therefore, we can through trade regulation and control, to promote economic, scientific and reasonable development of regional trade and to enhance the competitiveness of their products, and then to achieve enhancing regional economic competitiveness goals.

\section{References}

Adam Smith. (1972). The Nature and Causes of National Wealth. Beijing: Commercial Press, 1972:82.

Paul Krugman. (2001). International Trade Theory. Beijing: China Social Sciences Press.

Yingjuan Feng, Kexin Zheng. (2008). The Theory Study on Formation of Regional Economic Competitiveness and Enhancement. Changchun: Jilin University Press. 